\title{
Developing, Implementing, and Evaluating a Formal Pharmacist Mentorship Program
}

\author{
Carmine Nieuwstraten, Alice Huh, Gwen Liu, Karen Davis, and Lisa Dolovich
}

\begin{abstract}
Background: Mentoring is associated with positive professional and personal outcomes. However, there are few published data on mentoring programs for pharmacists.

Objective: To develop and evaluate a mentorship program for hospital pharmacists that was implemented at St Joseph's Healthcare Hamilton, in Hamilton, Ontario, by identifying the benefits and challenges that participants experienced and determining whether the program provided the necessary skills for a successful mentoring relationship.

Methods: A descriptive pilot study was performed between June 2007 and November 2008. Focus groups and self-administered questionnaires were conducted at two time points (after 3-4 months and at the end of the study period). The focus groups were conducted separately for mentors and mentees. Data were summarized by predefined categories. Quantitative data from the questionnaires were summarized as medians, minimums, and maximums, and qualitative survey data were transcribed and reviewed.

Results: Three mentors were each paired with a mentee. The mentees identified an average of 4 learning objectives. All of the mentees reported improvements in their self-perceived level of competency and skill within the mentoring relationship and their confidence in their ability to perform the functions of a hospital pharmacist. The job satisfaction of both mentors and mentees improved. Reported challenges were related to scheduling and documentation. Mentors and mentees reported high levels of overall satisfaction with the program, at both of the evaluation time points. Participants spent less than $60 \mathrm{~min} /$ week each on mentoring activities.
\end{abstract}

Conclusions: Both mentors and mentees benefited from the mentoring relationship.

Key words: mentoring, professional development, job satisfaction, professional relationship

Can J Hosp Pharm 2011;64(2):124-130

\section{RÉSUMÉ}

Contexte : Le mentorat est associé à des résultats positifs sur le plan professionnel et personnel. Il existe toutefois peu de données sur des programmes de mentorat pour les pharmaciens.

Objectif : Concevoir et évaluer un programme de mentorat pour les pharmaciens d'hôpitaux mis sur pied au St Joseph's Healthcare Hamilton, à Hamilton, en Ontario, en déterminant les avantages et les problèmes connus des participants et si le programme a conféré les compétences nécessaires à une relation de mentorat fonctionnelle.

Méthodes : Une étude pilote descriptive a été menée entre juin 2007 et novembre 2008. Des groupes de discussion et des questionnaires autoadministrés ont été réalisés à deux moments (après 3-4 mois et à la fin de l'étude). Les groupes de discussion étaient distincts pour les mentors et pour les mentorés. Les données ont été résumées selon des catégories prédéfinies. Les données quantitatives issues des questionnaires ont été résumées selon des médianes, des minimums et des maximums, et les données qualitatives dégagées des enquêtes ont été transcrites et analysées.

Résultats : Trois mentors ont été chacun appariés avec un mentoré. Les mentorés ont défini en moyenne quatre objectifs d'apprentissage. Tous les mentorés ont signalé des améliorations quant à leur perception de leur niveau de compétence et d'habileté dans le cadre de leur relation de mentorat et quant à leur confiance dans leur capacité à exécuter les tâches d'un pharmacien d'hôpital. Les mentors et les mentorés étaient également plus satisfaits de leur travail. Les problèmes signalés étaient liés aux horaires et à la documentation. Les mentors et les mentorés ont déclaré dans l'ensemble être très satisfaits du programme, aux deux moments d'évaluation. Chaque participant consacrait moins de 60 minutes par semaine à des activités de mentorat.

Conclusions : Les mentors autant que les mentorés ont bénéficié de la relation de mentorat.

Mots clés : mentorat, perfectionnement professionnel, satisfaction au travail, relation professionnelle

[Traduction par l'éditeur] 


\section{INTRODUCTION}

$\mathrm{M}$ entorship is defined as a formal or informal, mutually supportive long-term relationship between at least 2 individuals, often in a professional setting. ${ }^{1,2}$ Mentoring has been associated with a number of positive personal and professional outcomes, including professional growth, increased job satisfaction, ease of transition into a new practice area, increased competence, and improved recruitment and retention of staff. ${ }^{1,2}$ The literature contains examples of mentorship programs in a variety of health care disciplines (primarily nursing and medicine), as well as in education and business, ${ }^{3-9}$ but there are very few published data about established mentorship programs for pharmacists. Available reports on pharmacy mentorship have focused on mentoring for pharmacy faculty members or mentorship in a research setting. ${ }^{10-12} \mathrm{~A}$ recent article described a mentorship program created for pharmacists in primary care that emphasized the benefits of mentorship in helping pharmacists to integrate into a new environment. ${ }^{13}$

St Joseph's Healthcare Hamilton is a 650-bed academic teaching hospital affiliated with McMaster University. The pharmacy department has 1 director, 5 managers (1 of whom manages the retail pharmacies), and 27 inpatient staff pharmacists. The department is committed to providing excellent clinical care to patients in the hospital. The only formal clinical training program offered by the department is a 1-year hospital pharmacy residency program. Almost half of the department's pharmacists are also trained as preceptors for pharmacy residents and pharmacy students. There is no formal professional or clinical skills development curriculum in place for currently employed pharmacists, although biweekly education sessions are held to assist pharmacists in developing their clinical therapeutic knowledge. Although informal mentoring is part of the departmental culture, it has not been well defined, nor is formal mentoring activity required of staff. It was thought that establishing a formal mentorship program would give pharmacists an opportunity for professional development in a structured manner, would add another level of support to new staff in the department, and might increase the career satisfaction of more senior staff. In 2007, the pharmacy department received one-time funding from the Ontario Ministry of Health and Long-Term Care to develop, implement, and evaluate the Pharmacist Mentorship Program.

The overall goals of the funded project were to develop, implement, and evaluate a Pharmacist Mentorship Program at St Joseph's Healthcare Hamilton; to develop the skills and knowledge of pharmacists to function in the mentor and mentee roles; to provide opportunities for mentees to develop and pursue professional development goals in collaboration with mentors, within a structured environment; to provide career enrichment and improve the professional satisfaction of pharmacists; to utilize the program as a value-added recruitment and retention strategy; and to disseminate lessons learned through the program development process. It was anticipated that the Pharmacist Mentorship Program would facilitate professional growth and clinical practice competencies by formalizing a supportive relationship between a pharmacist mentor and mentee.

The objectives of the research component of the project were to identify the benefits and challenges that mentors and mentees experienced when participating in the Pharmacist Mentorship Program and to determine whether the program gave mentors and mentees the necessary skills for a successful mentoring relationship.

This paper describes the process used by the pharmacy department to complete the pilot project and reports the related research outcomes.

\section{PROGRAM AND RESOURCE DEVELOPMENT}

A steering committee (consisting of the authors of this paper) was established to guide project development and evaluation. The steering committee handled strategic planning, day-today operations, and the evaluation components of the project. A literature review was conducted (MEDLINE, International Pharmaceutical Abstracts), and an expert in the field of mentoring was contacted for input (Dr H Lee Kilty, Brock University, personal communication, May 24, 2007). In particular, a nursing mentorship document published by the Ontario Hospital Association ${ }^{1}$ was instrumental for developing the foundation on which the program was built. The program was designed such that each mentor-mentee pairing would continue for a minimum of 12 months (to ensure the establishment of strong relationships). ${ }^{1}$ Criteria for mentors and mentees were developed. A position description for mentors was developed that outlined key competencies and functions (Appendix 1, available online at www.cjhp-online.ca/index.php/cjhp/issue/view/ 80/showToc). A mentorship toolkit, including a manual and DVD, was created for use by mentors and mentees. The manual provided information on mentoring, adult learning styles, managing conflict, providing feedback, critical thinking, and developing learning objectives and associated action plans. The manual also included forms and guidelines to support the mentoring relationship and evaluate the program. Mentors also attended mentoring training workshops offered by the steering committee and/or the Program for Faculty Development at McMaster University. At the time of writing (late 2010), a series of modules was being developed to assist mentees and mentors in identifying and addressing learning needs (in research, management, clinical practice, and teaching). The pharmacy department plans to convert all of the program material to a web-based format that will be accessible through the hospital's intranet.

\section{METHODS}

The Pharmacist Mentorship Program was evaluated through a descriptive pilot study that ran from June 2007 to November 2008. The study was approved by the Research 
Ethics Board of St Joseph's Healthcare Hamilton. The following inclusion criteria were used to identify suitable participants. The mentors consisted of a convenience sample of pharmacists who had been employed for a minimum of 3 years in the department. The mentees consisted of a convenience sample of pharmacists who had been employed for less than 18 months in the department. Pharmacists in both groups volunteered to participate. Members of the steering committee were excluded from participating as mentors or mentees. The mentors and mentees were paired on the basis of information they provided through a matching form developed for the program (Appendix 2, available online at www.cjhp-online.ca/index.php/cjhp/ issue/view/80/showToc), results of the Kolb Learning Styles Inventory, ${ }^{14}$ and the Pharmacists' Inventory of Learning Styles. ${ }^{15}$

Mentors participated in a 3-h training workshop led by members of the steering committee. The workshop included an introduction to mentoring; a discussion of adult learning, communication skills, providing feedback, and critical thinking; case scenarios; and program operationalization. Mentees participated in individual orientation sessions presented by members of the steering committee.

All participants completed a pre- and post-training self-reflection exercise. Each mentor-mentee pair signed a mutual agreement form, which outlined the expectations of each party within the mentoring relationship ${ }^{16}$ (Appendix 3, available online at www.cjhp-online.ca/index.php/cjhp/issue/ view/80/showToc). Throughout the program, the mentormentee pairs met regularly (as mutually agreed by each pair). Using resources provided in the mentorship manual, mentees identified 2 or 3 learning objectives and created an action plan (Appendix 4, available online). Mentors provided support to the mentees during this process. Mentors and mentees were asked to complete weekly logs (Appendix 5, available online), which documented the types of mentoring activities completed each week, along with the time spent on these activities. Qualitative and quantitative data about the mentorship experience were collected from participants, by means of questionnaires and focus groups led by an external certified facilitator from the Faculty of Health Sciences, McMaster University. Both forms of evaluation were offered twice during the project: after 3-4 months (i.e., in September or October 2007), and at the end of the project (i.e., in November 2008). The questions in the questionnaire were categorized into skills and knowledge, quality of work life, workload, challenges, training, and general questions. The questionnaire data were subjected to descriptive analyses generating median, minimum, and maximum values. Qualitative data from open-ended survey responses were transcribed, and 2 members of the research group (G.L., C.N.) independently reviewed the responses and identified categories of responses. The focus groups were administered separately for mentors and mentees and followed a semistructured interview guide (Appendix 6, available online). The content from each focus group was transcribed verbatim. Two members of the steering committee (G.L., C.N.) independently reviewed the transcripts to identify themes. Data were summarized according to the categories in the focus group guide, and responses were collated.

As part of the funding allotment, mentors and mentees were given a stipend for their participation in the project (equivalent to 30 hours at overtime rate).

\section{RESULTS}

In total, 3 mentors and 3 mentees participated in the study. At the start of the program, the mentors had been employed at St Joseph's Healthcare Hamilton for an average of 4 years and the mentees for 1 year or less. In one of the mentor-mentee pairs, a perceived lack of benefit and a perceived lack of common goals for mentoring led to dissolution of the pairing. All available data, including partial data for the pair that was dissolved, are presented here.

On average, the mentor-mentee pairs met formally twice a month, with informal meetings in between. The meetings took place both during and after work hours. Mentees identified an average of 4 learning objectives. Their goals were related to improving knowledge in clinical therapeutics, developing learning portfolios, and learning about pharmacy medication management systems. Action plans included a variety of strategies to meet the learning objectives, such as readings, literature reviews, networking with colleagues at other facilities, and hands-on practice. Mentors reported spending an average of 50 and $45 \mathrm{~min} /$ week on mentoring activities at the initial evaluation (i.e., after 3-4 months) and the final evaluation, respectively. Mentees reported spending an average of 57.5 and $30 \mathrm{~min} /$ week at the initial and final evaluations, respectively.

\section{Questionnaire}

Mentees were asked to rate their ability to establish learning objectives on a scale of 1 to $10(1=$ not at all, $10=$ absolutely $)$. At the initial evaluation, the median rating for the 3 mentees was 7 (minimum 6, maximum 9). At the end of the study, both of the remaining mentees rated their ability at 8 . Mentees also rated their ability to fulfill their learning objectives through the defined action plans. At the initial evaluation, the median rating was 8 (minimum 6 , maximum 10), and at the end of the study, the rating was 8 for both mentees.

Mentors and mentees were asked to assess their perceived level of competency and skill demonstrated in the mentoring relationship. At the initial evaluation, all 3 mentors and 2 of the mentees reported some improvement, and the third mentee reported significant improvement. At the end of the study, all participants reported some improvement. Mentors and mentees were also asked if their confidence in their ability to perform the functions of a hospital pharmacist had improved after joining the mentorship program (rated on scale of 1 to 10 , as above). Both mentors and mentees reported increased confidence over the course of the project (Table 1). Mentors were also asked if the Pharmacist Mentorship Program had given them sufficient 


\section{Table 1. Perceptions of Mentors and Mentees Regarding Effects of the Pharmacy Mentorship Program*}

\begin{tabular}{|c|c|c|c|c|}
\hline \multirow[t]{2}{*}{ Topic } & \multicolumn{2}{|c|}{ Mentors } & \multicolumn{2}{|c|}{ Mentees } \\
\hline & $\begin{array}{l}\text { Initial } \\
(n=3)\end{array}$ & $\begin{array}{c}\text { Final } \\
(n=2)\end{array}$ & $\begin{array}{l}\text { Initial } \\
(n=3)\end{array}$ & $\begin{array}{c}\text { Final } \\
(n=2)\end{array}$ \\
\hline $\begin{array}{l}\text { Confidence } \\
\text { Median } \\
\text { Minimum } \\
\text { Maximum }\end{array}$ & $\begin{array}{l}6 \\
4 \\
7\end{array}$ & $\begin{array}{l}\text { NA } \\
6 \\
8\end{array}$ & $\begin{array}{l}6 \\
6 \\
9\end{array}$ & $\begin{array}{l}\text { NA } \\
8 \\
9\end{array}$ \\
\hline $\begin{array}{l}\text { Job satisfaction } \\
\text { Median } \\
\text { Minimum } \\
\text { Maximum }\end{array}$ & $\begin{array}{l}6 \\
6 \\
9\end{array}$ & $\begin{array}{l}\text { NA } \\
7 \\
9\end{array}$ & $\begin{array}{l}6 \\
6 \\
7\end{array}$ & $\begin{array}{l}\text { NA } \\
7 \\
8\end{array}$ \\
\hline $\begin{array}{l}\text { Usefulness of training materials } \\
\text { and tools } \\
\text { Median } \\
\text { Minimum } \\
\text { Maximum }\end{array}$ & $\begin{array}{l}7 \\
6 \\
8\end{array}$ & $\begin{array}{l}\text { NA } \\
6 \\
8\end{array}$ & $\begin{array}{l}8 \\
7 \\
8\end{array}$ & $\begin{array}{l}\text { NA } \\
7 \\
8\end{array}$ \\
\hline $\begin{array}{l}\text { Overall satisfaction with program } \\
\text { Median } \\
\text { Minimum } \\
\text { Maximum }\end{array}$ & $\begin{array}{l}7 \\
6 \\
8\end{array}$ & $\begin{array}{c}\text { NA } \\
7 \\
8\end{array}$ & $\begin{array}{l}8 \\
6 \\
9\end{array}$ & $\begin{array}{l}\text { NA } \\
8.5 \\
9\end{array}$ \\
\hline
\end{tabular}

knowledge and confidence to be a mentor. The median rating for mentors was 6 (minimum 5, maximum 9) at the initial evaluation, and the ratings were 7 and 9 at the final assessment.

At both the initial evaluation and the end of the study, the mentors listed a number of factors motivating them to participate in the project as a mentor: wanting to support the department, benefiting from a past experience in a positive mentoring relationship, acting as a support to new staff, and helping to recognize the mentoring role in everyday encounters. Motivating factors for mentees included increased comfort level in a new career, development of a professional relationship with another pharmacist, and establishing and meeting new learning goals.

Mentors and mentees were asked if their level of job satisfaction had improved through participation in the Pharmacist Mentorship Program. Both mentors and mentees reported increased levels of job satisfaction at the final evaluation (Table 1).

Mentors were asked to rate the usefulness of the training workshop. At the initial evaluation, the median rating was 8 (minimum 5, maximum 9), and at the final evaluation, the ratings were 6 and 10. Participants were also asked to rate the usefulness of the tools that had been developed for the program. At both the initial and the final evaluation, the tools were reported to be somewhat helpful (Table 1), with little change in results over time.

Mentors and mentees were asked to describe obstacles or challenges that they had encountered in the mentoring relationship. Both groups identified scheduling difficulties (in terms of scheduling meetings and completing learning objectives) and the significant requirements for documentation as challenges at both the initial and the final evaluations. When asked to provide feedback on potential improvements to the program, participants suggested promoting the program to all department staff, simplifying and/or streamlining the training materials, offering the training materials online, and formally recognizing the contributions of participants.

All mentors and mentees indicated that they would have participated in the program even if there had been no financial compensation.

When overall satisfaction with the Pharmacist Mentorship Program was ranked on a scale of 1 to 10 (where $1=$ not at all satisfied and $10=$ absolutely satisfied), both mentors and mentees reported high levels of satisfaction at both evaluation time points (Table 1).

\section{Focus Groups}

The major themes from the focus groups were similar at both the initial and the final evaluations (see Table 2). Specific definitions within these major themes varied slightly between mentors and mentees. Improved job satisfaction, professional development, relationship-building, and staff recruitment and retention were consistently identified as benefits of mentoring. Mentees also noted a smooth transition to their respective careers as a benefit. Mentors and mentees identified effective matching and adequate training (including the training materials) as key features for a successful mentoring relationship. Time constraints, scheduling difficulties, and documentation requirements were noted as challenges of the program. Mentors felt that providing sufficient support to mentors was important to consider for sustaining the program over the long term. Mentees 
Table 2. Focus Group Themes

\begin{tabular}{|c|c|c|c|c|}
\hline \multirow[t]{2}{*}{ Theme } & \multicolumn{2}{|c|}{ Mentor Definitions } & \multicolumn{2}{|c|}{ Mentee Definitions } \\
\hline & Initial Evaluation & Final Evaluation & Initial Evaluation & Final Evaluation \\
\hline Mentoring is beneficial & $\begin{array}{l}\text { - Improved job } \\
\text { - } \text { satisfaction } \\
\text { - Incressional growth } \\
\text { - Relationship-building } \\
\text { - Recruitment and } \\
\text { retention of staff }\end{array}$ & $\begin{array}{l}\text { - Complements clinical } \\
\text { role } \\
\text { - Skill development } \\
\text { - Relationship-building } \\
\text { - Rewarding }\end{array}$ & $\begin{array}{l}\text { - Improved staff } \\
\text { - } \text { Patisfaction } \\
\text { Professional } \\
\text { development, learning } \\
\text { opportunities } \\
\text { - Relationship-building } \\
\text { - Recruitment and } \\
\text { retention of staff } \\
\text { - Smooth transition } \\
\text { to career } \\
\text { - Support from } \\
\text { experienced staff } \\
\text { - Improved department } \\
\text { morale } \\
\text { - Self-assessment } \\
\text { - Teamwork } \\
\text { - Improved } \\
\text { communication }\end{array}$ & $\begin{array}{l}\text { - Professional satisfaction } \\
\text { - Professional } \\
\text { development } \\
\text { - Relationship-building } \\
\text { - Rewarding } \\
\text { - Recruitment and } \\
\text { retention of staff } \\
\text { - Smooth transition to } \\
\text { career } \\
\text { - Positive work } \\
\text { environment }\end{array}$ \\
\hline Keys to successful mentoring & $\begin{array}{l}\text { - Thorough matching } \\
\text { process } \\
\text { - Adequate training } \\
\text { - Dedicating time to } \\
\text { relationship } \\
\text { - Patience }\end{array}$ & $\begin{array}{l}\text { - Enthusiasm } \\
\text { - Written materials } \\
\text { - Support } \\
\text { - Patience }\end{array}$ & $\begin{array}{l}\text { - Effective matching } \\
\text { - Training material } \\
\text { - Support from mentor } \\
\text { - Structured program }\end{array}$ & $\begin{array}{l}\text { - Effective matching } \\
\text { - Eagerness and } \\
\text { willingness to learn } \\
\text { - Effective } \\
\text { communication }\end{array}$ \\
\hline Challenges of mentoring & $\begin{array}{l}\text { - Time and scheduling } \\
\text { - Documentation } \\
\text { requirements } \\
\text { - Risk of transference }\end{array}$ & $\begin{array}{l}\text { - Time and scheduling } \\
\text { - Documentation } \\
\text { requirements }\end{array}$ & $\begin{array}{l}\text { - Scheduling } \\
\text { - Documentation } \\
\text { - Motivation }\end{array}$ & $\begin{array}{l}\text { - Time and scheduling } \\
\text { - Documentation }\end{array}$ \\
\hline Sustaining mentoring & $\begin{array}{l}\text { - Sufficient number of } \\
\text { participants } \\
\text { - Less formality } \\
\text { - Support of mentors } \\
\text { - Coordination by } \\
\text { nonmanagement staff }\end{array}$ & $\begin{array}{l}\text { - Feedback to mentors } \\
\text { - Ongoing program } \\
\text { evaluation } \\
\text { - Management support } \\
\text { - Share learnings }\end{array}$ & $\begin{array}{l}\text { - Promote in department } \\
\text { - Less formality } \\
\text { - Value participants } \\
\text { - Involvement of } \\
\text { front-line staff }\end{array}$ & $\begin{array}{l}\text { - Promote in } \\
\text { department }\end{array}$ \\
\hline
\end{tabular}

felt that the program should be promoted in the department to ensure its sustainability. Box 1 lists some narrative quotes from the participants to highlight their experience with the program.

\section{DISCUSSION}

Pharmacists involved in the Pharmacist Mentorship Program at St Joseph's Healthcare Hamilton found the program to be valuable, rewarding, and enjoyable, and there was a sense of pride among those who participated in the project. Mentees were successful in identifying and meeting learning objectives throughout the project. Both the mentors and the mentees noted that their confidence in performing hospital pharmacist functions increased over the course of the mentoring period. This may suggest that having a supportive relationship provides reciprocity and sharing of clinical knowledge of benefit to both mentor and mentee.

Both mentors and mentees reported increased job satisfaction through participation in the program. Mentors rated this aspect more highly than mentees, which suggests that involving experienced employees in this type of program has a positive impact on the quality of their work life, which is a factor in staff retention. The lower ratings by mentees at the initial evaluation may simply reflect insufficient time to fully assess outcomes related to satisfaction. Compatible pairings between mentors and mentees appeared to be associated with greater satisfaction within the program.

Mentors reported increased self-confidence in their ability to be a mentor over the duration of the project. This is an important finding, as some of the mentors, when initially approached about the project, were unsure about their ability to mentor. The training provided to mentors was helpful in preparing them for this role.

The time spent on mentoring activities was not perceived as excessive by any of the participants, and the time required decreased over the course of the project, perhaps because the participants became more familiar with the mentoring process and relationship and there was less ongoing documentation to be completed as the project progressed.

Similar themes were identified in the 2 focus groups. The positive experience of the Pharmacist Mentorship Program was highlighted, along with many specific benefits to the mentors and 
mentees, the pharmacy department, and the hospital. The identified benefits were consistent with those reported in other published studies of mentoring, including increased job satisfaction, increased confidence, and successful transition to new position. ${ }^{1,3-13}$ Challenges with scheduling and documentation were identified. These challenges had been anticipated, as the Pharmacist Mentorship Program was an added responsibility of the participants, on top of their clinical work. Focus group themes and the qualitative data categories in the questionnaire contained a number of similar descriptions, which may allow informal validation of the findings. In the second focus group (i.e., at the end of the project), the theme definitions provided by both mentors and mentees seemed to focus more on personal rewards and relationship-building, perhaps indicating how growth of the mentoring relationship over the long term led to lasting impact on self-worth and noticeable positive benefits.

Overall satisfaction with the Pharmacist Mentorship Program was high and increased over time for both mentors and mentees. This result supports the understanding that long-term mentoring relationships are needed to achieve maximum benefits.

The ability to capture long-term meaningful outcomes was limited by the short timeframe and small sample size of the study. Because this was a small pilot study, it was not possible to draw any significant statistical conclusions from the data. However, the descriptive nature of the data will be helpful in modifying the program to better meet the needs of participants. The structure of the program inherent in the research study protocol (particularly in terms of documentation) was more formal than generally recommended for mentoring relationships. For example, mentors and mentees completed weekly learning logs to document their mentoring activities. The participants found that it was challenging to consistently complete these logs. However, the information collected through this documentation allowed them to review and highlight what they had accomplished.

Through this project, the steering committee (the authors of this article) learned a tremendous amount about mentoring (including differences between mentoring and precepting, mentoring theory, outcomes and evaluation of mentoring, methods for mentor-mentee pairing) and also learned how a mentoring program can complement other programs in the department (specifically the pharmacy residency program and undergraduate pharmacy student placements) to facilitate personal and professional growth.

An important initial step in the program's development was to clearly distinguish the differences between mentoring and precepting. Although members of the steering committee were well versed in the characteristics and functions of a preceptor, the role of a mentor needed clear definition. Summary charts identifying key differences between mentors and preceptors were available and were adapted for use in the project. ${ }^{2,17} \mathrm{~A}$ mentoring relationship is generally long-term, nurturing, and

\section{Box 1. Narrative Quotations from Participants}

\section{Mentees}

"I've had someone to help guide my professional development and push me in directions I would not have gone on my own."

"I'm meeting learning objectives that I may not have otherwise."

"In the process of the mentorship program, the relationship developed not only professionally but at a friendship level as well. This is very valuable and fulfilling."

"I have been able to learn a lot from my mentor and it adds an extra level of comfort knowing there is someone to turn to if I have questions or concerns."

"I have learned a lot from my mentor about the role of a clinical pharmacist, about professionalism, about how to approach problems or challenging situations."

"Having pharmacists in a mentoring relationship strengthens both and creates a positive work environment."

"One needs to be able to accept new ideas, different ways of thinking or problem solving in order to get the most [out] of being a mentee."

\section{Mentors}

"I feel as though I was helping my mentee gain confidence and enjoyed noticing how they were succeeding in meeting their goals and objectives."

"[I have] a sense of confidence in my ability to enhance the professional growth of a colleague."

"The [Pharmacist Mentorship Program] frees the mentee to develop apart from scrutiny and performance practice."

based on a role model. It is both professional and personal in nature and focuses on supporting the ongoing learning needs of the mentee, with interactions often occurring during personal time. In contrast, a precepting relationship is generally shortterm (with a predetermined duration), formal, and professional. It is focused on specific learning related to meeting the objectives of the rotation, with interactions occurring mostly during work hours.

One of the mentoring pairs dissolved their relationship before the end of the project. A member of the steering committee met with the pair to review the reasons for dissolving the relationship and to ensure that closure took place. Working through this event reinforced the need for a strong initial matching process, as well as the need to ensure that supports are in place to allow a formal end to the mentoring partnership while maintaining a professional and collegial relationship in the department.

Data obtained during the focus groups regarding keys to success and sustainability for the program (such as successful matching, mentor patience, support and structure for mentees, ongoing input from management, and integration into the departmental culture) will be instrumental in improving the program. 


\section{Next Steps}

On the basis of feedback from participants in the Pharmacist Mentorship Program, a number of enhancements to the program are planned. The training material and documentation forms will be streamlined and transformed for online delivery. The program will be promoted within the department, and new mentors and mentees will be recruited. Processes will be developed to ensure that mentors receive ongoing support from the program coordinators. Regular, but separate, sessions with mentors and mentees will be arranged to encourage discussion and sharing of both positive and negative experiences. Eventually, it is hoped that a similar program will be offered for the pharmacy technicians in the department. There are also opportunities to share the program's framework and materials with other health care disciplines at St Joseph's Healthcare Hamilton.

\section{CONCLUSION}

The pharmacist mentorship pilot project at St Joseph's Healthcare Hamilton was well received by participants. The department plans to continue offering this program.

\section{References}

1. Lee Kilty H. The Nurse Mentorship Pilot Project: resources for mentors. Toronto (ON): Ontario Hospital Association; 2006 [cited 2007 Apr 17]. Previously available from: www.oha.com/Client/OHA/OHA_LP4W_ LND_WebStation.nsf/resources/Nurse+Mentorship+Pilot+Project/\$file/ Resources+for+Mentors+-+FINAL+-+April+2006.pdf

2. Kilcher A, Sketris I. Mentoring resource book: a guide for faculty, researchers and decision makers. Halifax (NS): Dalhousie University, College of Pharmacy; 2003.

3. Andrews M, Wallis M. Mentorship in nursing: a literature review. J Adv Nurs 1999;29(1):201-207.

4. Hurst S, Koplin-Baucum S. Role acquisition, socialization, and retention: unique aspects of a mentoring program. I Nurses Staff Dev 2003;19(4):176-180.

5. Dyer L. The continuing need for mentors in nursing. J Nurses Staff Dev 2008;24(2):86-90.

6. Ehrich L, Tennent L, Hansford B. A review of mentoring in education: some lessons for nursing. Contemp Nurse 2002;12(3):253-264.

7. Buddeberg-Fischer B, Vetsch E, Mattanza G. Career support in medicine-experiences with a mentoring program for junior physicians at a university hospital. Pyschosoc Med 2004;1:Doc04.

8. Yeung M, Nuth J, Stiell IG. Mentoring in emergency medicine: the art and the evidence. CJEM 2010;12(2):143-149.

9. Sambunjak D, Staus SE, Marusić A. Mentoring in academic medicine: a systematic review. JAMA 2006;296(9):1103-1115.

10. Fuller K, Maniscalco-Feichtl M, Droege M. The role of the mentor in retaining junior pharmacy faculty members. Am J Pharm Educ 2008; $72(2): 41$.

11. Zeind CS, Zdanowicz M, MacDonald K, Parkhurst C, King C, Wizwer P. Developing a sustainable faculty mentoring program. Am J Pharm Educ 2005;69(5):Article 100.
12. Sauer KA, Hepfinger CA, Wilhardt MS, Sahni S, Weber EW, Koontz R. Pharmacy research mentoring. Am J Health Syst Pharm 2004;61(23): 2552-2556.

13. Farrell B, Dolovich L, Austin Z, Sellors C. Implementing a mentorship program for pharmacists integrating into family practice: practical experience from the IMPACT project team. Can Pharm J 2010;143(1):28-36.

14. Kolb learning styles inventory. Hay Resources; [cited 2007 May 5]. Previously available from: www.hayresourcesdirect.haygroup.com/lsi/ default-new.asp?oz=842

15. Austin Z. Development and validation of the Pharmacists' Inventory of Learning Styles (PILS). Am J Pharm Educ 2004;68(2):Article 37.

16. Noesgaard C, Kustra E, Walsh A. Mentorship: What's it all about? [workshop materials]. Hamilton (ON): McMaster University, Program for Faculty Development, Centre for Leadership in Learning, Education Research Unit; 2007.

17. Preceptorship resource kit. Toronto $(\mathrm{ON})$ : Registered Nurses' Association of Ontario; 2004.

Carmine Nieuwstraten, RPh, BScPhm, ACPR, is Professional Practice Leader in the Pharmacy Department, St Joseph's Healthcare Hamilton, in Hamilton, Ontario. She is also a Teaching Associate, Leslie Dan Faculty of Pharmacy, University of Toronto, Toronto, Ontario.

Alice Huh, RPh, BScPhm, ACPR, is the Manager of Pharmacy Technical Services, Pharmacy Department, St Joseph's Healthcare Hamilton, in Hamilton, Ontario. She is also a Teaching Associate, Leslie Dan Faculty of Pharmacy, University of Toronto, Toronto, Ontario.

Gwen Liu, RPh, BScPhm, PharmD, ACPR, is Pharmacy Project Resource Pharmacist, Pharmacy Department, St Joseph's Healthcare Hamilton, in Hamilton, Ontario.

Karen Davis, RPh, BScPhm, MBA, is a Pharmacotherapy Specialist in the Pharmacy Department, St Joseph's Healthcare Hamilton, in Hamilton, Ontario

Lisa Dolovich, BScPhm, PharmD, MSc, is Research Director and Associate Professor with the Department of Family Medicine, McMaster University, Hamilton, Ontario. She is also a Scientist and Associate Director, Centre for Evaluation of Medicines in Hamilton.

\section{Address correspondence to:}

Carmine Nieuwstraten

Pharmacy Department

St Joseph's Healthcare Hamilton

50 Charlton Avenue East

Hamilton ON L8N 4A6

e-mail: cnieuwst@stjoes.ca

\section{Acknowledgement}

The development, implementation, and evaluation of the Pharmacist Mentorship Program was supported by a one-time grant from the Ontario Ministry of Health and Long-Term Care. 